Original Research Paper

\title{
Structure of a Photovoltaic Electric Locomotive
}

\author{
Florian Ion Tiberiu Petrescu \\ ARoTMM-IFToMM, Bucharest Polytechnic University, Bucharest, (CE), Romania
}

Article history

Received: 22-08-2019

Revised: 02-09-2019

Accepted: 16-11-2019

Email: scipub02@gmail.com

\begin{abstract}
The paper proposes to start studies at the global level for the implementation of photovoltaic electric locomotives. The question the author asks is why such trains have not been implemented so far, is there no interest in such a thing? This may avoid the current rush to implement $5 \mathrm{G}$ technologies in an already extremely dangerous form for humanity, the rush justified by the politicians by the need to quickly implement the massive wireless power transmission for cars, trains, vehicles, drones, airplanes. In the rush to have massive energy transmitted wirelessly to power vehicles, trains, drones, airplanes, current governments of the world's largest countries, they rush to unleash $5 \mathrm{G}$ technologies in a form extremely dangerous to humanity. Interestingly, their implementation will start in smaller countries that do not have much right to replicate in the face of the world's great powers. How did all this human madness, called superior technology, start? There is at present an unseen war between the partisans of the continued use of internal combustion engines and those of the rapid deployment of electric motors everywhere. The global energy crisis haunted mankind several times in its history but the most serious was the one that preceded the economic-financial crisis of 1933, after which two world wars followed, with about 200 million dead, that is, one- fifth of one billion, with massive destruction, but also with a rapid imputation of the population of the globe that had started to grow exponentially. The world forgot that shock and slowly began to recover until the 1970s and 1980s when the major energy crisis began again to haunt humanity. Trams, subways, trolleybuses and nuclear fission energy were added, which at that time and now represented a major evil needed. Much has been gained for mankind, during which time renewable, sustainable energy resources, already massively implemented around the globe, have emerged, although their pace of massive implementation may still be increasing. Recently, a group of researchers from a prestigious university in Switzerland managed to synthesize superior gasoline, kerosene-type, usable in aviation, from the air and photovoltaic energy. A single plant of this type, spread over several hectares, will be able to produce annually all the amount of superior gasoline needed for all the vehicles on the planet, airplanes, cars, trains, ships ... And it will use only the air that recovers and photovoltaic solar energy.
\end{abstract}

Keywords: Energy, Locomotives, Electric Locomotives, Photovoltaic Electric Locomotives, 5G Technologies in an Already Extremely Dangerous form for Humanity

\section{Introduction}

In the rush to have massive energy transmitted wirelessly to power vehicles, trains, drones, airplanes, current governments of the world's largest countries, they rush to unleash $5 \mathrm{G}$ technologies in a form extremely dangerous to humanity. Interestingly, their implementation will start in smaller countries that do not have much right to replicate in the face of the world's great powers.

How did all this human madness, called superior technology, start? There is at present an unseen war between the partisans of the continued use of internal 
combustion engines and those of the rapid deployment of electric motors everywhere.

What can we say about maintaining internal combustion Engines. The global energy crisis haunted mankind several times in its history but the most serious was the one that preceded the economicfinancial crisis of 1933, after which two world wars followed, with about 200 million dead, that is, one-fifth of one billion, with massive destruction, but also with a rapid imputation of the population of the globe that had started to grow exponentially.

The world forgot that shock and slowly began to recover until the 1970s and 1980s when the major Energy crisis began again to haunt humanity.

At that time when oil and natural gas were rapidly depleting, the price increase for petrol, diesel and gas began to rise permanently, but $70 \%$ of the electric trains were introduced quickly in all civilized countries. Trams, subways, trolleybuses and nuclear fission energy were added, which at that time and now represented a major evil needed.

Much has been gained for mankind, during which time renewable, sustainable energy resources, already massively implemented around the globe, have emerged, although their pace of massive implementation may still be increasing.

Today, when the pace of wind and photovoltaic energies has increased a lot, when we still have raw materials for the existing nuclear power plants, we have managed to discover and especially to exploit the system gases from the deep, thanks to the superior technologies implemented. In the meantime, the old oil reserves have been restored and new ones have appeared, but the newly discovered shale gases alone allow the global Energy resistance for another two or even three thousand years. Also, in the United Kingdom, a group of scientific researchers has obtained gas from the air by using carbon from the air, which is a toxic, undesirable product and which has led largely to the undesirable global warming of our planet. Recently, a group of researchers from a prestigious university in Switzerland managed to synthesize superior gasoline, kerosene-type, usable in aviation, from the air and photovoltaic energy. A single plant of this type, spread over several hectares, will be able to produce annually all the amount of superior gasoline needed for all the vehicles on the planet, airplanes, cars, trains, ships ... And it will use only the air that recovers and photovoltaic Solar Energy.

In these conditions, knowing that electric motors also pollute, but especially the batteries of electric vehicles are extremely polluting, the Otto engine and the diesel engine can acquire new brains and obviously the energy crisis that has grinded us for decades seems to have away from us.

Fans of the electric motor, slightly scared, knowing that the main reason why the electric motor was delayed to develop and be introduced on all cars and airplanes is that it requires a real energy source that cannot be generally photovoltaic being insufficient even then the source will be an electric generator with gas or gasoline, the one that returns us to the combustion engines, so the electric motor followers have thought about powering the electric cars on the go and the airplanes and drones alike, wirelessly. This requires the transmission of massive energy through waves, an energy that is also very dangerous to humans and animals.

For this reason, the introduction of $5 \mathrm{G}$ technologies that will enable the switch to wireless power is now being forced.

We now have nuclear power at our discretion and soon nuclear power through fusion, which is totally friendly, green and sustainable (Halliday and Robert, 1966; Kramer, 2011; Krane, 1987; Mânzatu, 1969; Moses et al., 2009; Shultis and Faw, 2002; Tomonaga, 1997; Wichmann, 1983; Petrescu and Calautit, 2016a-b; Petrescu and Petrescu, 2014, 2019; Petrescu et al., 2016; Petrescu, 2012a-b, 2014, 2019).

Why it is necessary to force these $5 \mathrm{G}$ technologies still technically unorganized, extremely harmful to humans and animals and why we must speed up the transmission of massive wireless power, at the cost of our health and the lives of many people and animals. This is prohibited by all the constitutions of the countries of the planet and by all the UN norms ... How is it possible to implement some technologies that now function as weapons of mass destruction only in the desire to be able to rapidly transmit massive wireless Energy.

\section{Materials and Methods}

A car built by some Swedish students has proven that about three to four square meters of photovoltaics can provide the necessary energy for a motor of about 20-30 kw. For a train locomotive that needs an electric motor of $2000-3000 \mathrm{~kW}$, an area of 100 times larger photovoltaic will be required for the energy of the locomotive to be fully supplied during the day. Therefore, an area of about 300-400 square meters will be required.

A $30 \mathrm{~m}$ long electric locomotive can be built to a length of $40 \mathrm{~m}$ and with a height of about $4 \mathrm{~m}$, it will have an available area of $320 \mathrm{sq} \mathrm{m}$ on its two sides. And with those about 120 square meters above it will reach a total area of 440 square meters, photovoltaic, enough to operate the engine of about $3000 \mathrm{~kW}$ of the locomotive and the whole train with wagons. By the way, the wagons with 
photovoltaics can also be built so that we have an increased energy at the locomotive.

Thus we have electric trains and trams that will no longer consume from the national network, but only from the sun, we will no longer have the big losses on the network, the difficulties of building and maintaining the networks for trains networks of about $27000 \mathrm{~V}$ voltage extremely dangerous for those who have to work with it but also for the for those who are getting too close to these networks or wires who accidentally approach such wires and are deadly from 1-2 $\mathrm{m}$ distance. A lot of inconveniences disappear, safety in operation increases and you will not even need to talk about the need for a wireless power supply of trains. Everyone will be pleased.

In the short term with the will and patience, such systems can be built for cars, buses, ships, airships, aerospace farms, or energy stations on the Moon and Mars.

Airplanes that cannot yet be solar powered because they now require much higher energy will continue to work with kerosene, gas, hydrogen, or mixed. And the subway will continue to be supplied with high voltages on the traditional system.

The grading will be huge immediately after the implementation of the photovoltaic electric trains.

Let's now drop 5G right away until these technologies will no longer pose any danger to humans and animals, to life.

\section{Results and Discussion}

We are forced to implement 5G. The move from $4 \mathrm{G}$ to $5 \mathrm{G}$ is already a crime and genocide (Fig. 1).

The level of radiation used is already far too high and if used as desired in the initial project and microwaves (which are practically a lethal weapon usually used only in military applications and what is right in very small quantity in microwave ovens but and there cooked food loses everything bio) we can say that $5 \mathrm{G}$ is the beginning of the end. The microwaves penetrate deep into the tissues and burn the organic cells. Decades ago, after the Second World War, in the first attempt to transmit higher energy through microwaves, somewhere in the US desert, they also hit a flock of sheep with herds that immediately bled and animals and people. Since then microwaves are used for the transport of energies only to lethal weapons. The fact that the initial $5 \mathrm{G}$ project was also proposed with microwaves is extremely serious for humanity.

Hundreds of birds have fallen from the sky in The Hague, the Netherlands, during a $5 \mathrm{G}$ experiment to see how large the range was and whether the new wireless technology would cause any harm in the local area; Fig. 1.

It has happened and in other parts of the world, including Australia, but people didn't know what the cause was. It is trying to hide these facts and in no case to give up this harmful $5 \mathrm{G}$ to humanity.

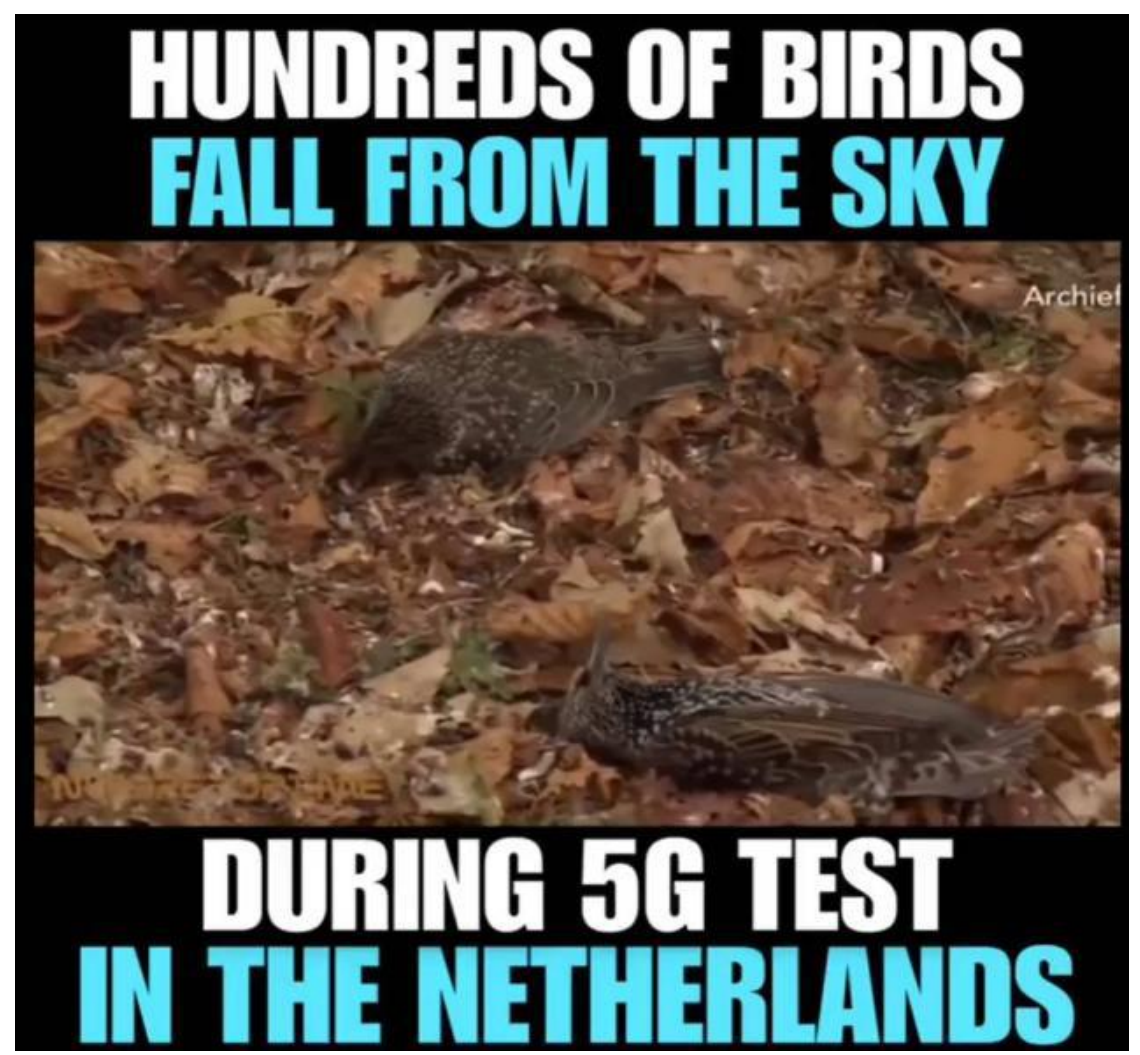

Fig. 1: Hundreds of birds have fallen from the sky in The Hague, the Netherlands, during a 5G experiment 


\section{Conclusion}

A car built by some Swedish students has proven that about three to four square meters of photovoltaics can provide the necessary energy for a motor of about 20-30 kw. For a train locomotive that needs an electric motor of 2000-3000 kW, an area of 100 times larger photovoltaic will be required for the energy of the locomotive to be fully supplied during the day. Therefore, an area of about 300400 square meters will be required.

A $30 \mathrm{~m}$ long electric locomotive can be built to a length of $40 \mathrm{~m}$ and with a height of about $4 \mathrm{~m}$, it will have an available area of $320 \mathrm{sq} \mathrm{m}$ on its two sides. And with those about 120 square meters above it will reach a total area of 440 square meters, photovoltaic, enough to operate the engine of about $3000 \mathrm{~kW}$ of the locomotive and the whole train with wagons. By the way, the wagons with photovoltaics can also be built so that we have an increased energy at the locomotive.

Thus we have electric trains and trams that will no longer consume from the national network, but only from the sun, we will no longer have the big losses on the network, the difficulties of building and maintaining the networks for trains networks of about $27000 \mathrm{~V}$ voltage extremely dangerous for those who have to work with it but also for the for those who are getting too close to these networks or wires who accidentally approach such wires and are deadly from $1-2 \mathrm{~m}$ distance. A lot of inconveniences disappear, safety in operation increases and you will not even need to talk about the need for a wireless power supply of trains. Everyone will be pleased.

We are forced to implement $5 \mathrm{G}$. The move from $4 \mathrm{G}$ to $5 \mathrm{G}$ is already a crime and genocide.

The level of radiation used is already far too high and if used as desired in the initial project and microwaves (which are practically a lethal weapon usually used only in military applications and what is right in very small quantity in microwave ovens but and there cooked food loses everything bio) we can say that $5 \mathrm{G}$ is the beginning of the end. The microwaves penetrate deep into the tissues and burn the organic cells. Decades ago, after the Second World War, in the first attempt to transmit higher energy through microwaves, somewhere in the US desert, they also hit a flock of sheep with herds that immediately bled and animals. and people. Since then microwaves are used for the transport of energies only to lethal weapons. The fact that the initial $5 \mathrm{G}$ project was also proposed with microwaves is extremely serious for humanity. Hundreds of birds have fallen from the sky in The Hague, the Netherlands, during a $5 \mathrm{G}$ experiment to see how large the range was and whether the new wireless technology would cause any harm in the local area.

It has happened and in other parts of the world, including Australia, but people didn't know what the cause was. It is trying to hide these facts and in no case to give up this harmful $5 \mathrm{G}$ to humanity.

\section{Acknowledgement}

The authors acknowledge INIS for their research in the field.

\section{Funding Information}

Research contract: Contract number 36-5-4D/1986 from 24IV1985, beneficiary CNST RO (Romanian National Center for Science and Technology) Improving dynamic mechanisms internal combustion engines.

\section{!All these matters are copyrighted!}

\section{Copyrights:}

1. New Aircraft (New Ionic or Beam Engines): no. 548 of 22-04-2010 [cgiywDssin], Aerospace Engineering

2. Some Few Specifications About the Doppler Effect to the Electromagnetic Waves: 636 of 28-05-2010 [iEtcaouxxA], physics

3. Presenting an Atomic Model and Some Possible Applications in LASER Field: nr. 639 of 29-052010 [yncngrotfo], physics

4. Some Applications in LASER Field: no. 718 of 0907-2010 [xeujouincC], physics

5. The Energies of Today and Tomorrow: nr. 819 of 30-09-2010 [kbHquxwykr], energy engineering

6. Obtaining Energy by the Annihilation of the Matter with Antimatter - The Battle for Energy: nr. 1068 of 13.03.2011 [GfEqpGDzeh], Energy Engineering

\section{Ethics}

This article is original and contains unpublished material. Authors declare that are not ethical issues and no conflict of interest that may arise after the publication of this manuscript.

\section{References}

Halliday, D. and R. Robert, 1966. Physics, Part II. 1st Edn., John Wiley and Sons, Inc., New York.

Kramer, D., 2011. DOE looks again at inertial fusion as a potential clean-energy source. Phys. Today, 64: 26-26. DOI: 10.1063/1.3563814

Krane, K.S., 1987. Introductory Nuclear Physics. 3rd Edn., Wiley Sons, New York, pp: 864. ISBN-10: 047180553X

Mânzatu, I., 1969. Polarization and orientation in nuclear physics: Quantum basics of spinal polarization. Academia RSR Publishing House.

Moses, EI., R.N. Boyd, B.A. Remington, C.J. Keane and R. Al-Ayat, 2009. The national ignition facility: Ushering in a new age for high energy density science. Phys. Plasmas, 16: 041006-041006.

DOI: $10.1063 / 1.3116505$ 
Petrescu, F.I.T. and J.K. Calautit, 2016a. About nano fusion and dynamic fusion. Am. J. Applied Sci. 13: 261-266.

DOI: 10.3844/ajassp.2016.261.266

Petrescu, F.I.T. and J.K. Calautit, 2016b. About the light dimensions. Am. J. Applied Sci., 13: 321-325.

DOI: 10.3844/ajassp.2016.321.325

Petrescu, F.I.T. and R.V.V. Petrescu, 2019. Nuclear hydrogen structure and dimensions. Int. J. Hydrogen Energy, 44: 10833-10837.

DOI: 10.1016/j.ijhydene.2019.02.140

Petrescu, F.I.T. and RV. Petrescu, 2014. Nuclear Green Energy, I.J.A.P., 10: 3-14.

Petrescu, F.I.T., 2019. About the nuclear particles' structure and dimensions. Comp. Part. Mech.

Petrescu, FIT., 2012a. Cold nuclear fusion. Plasma Physics Fusion Technol.
Petrescu, F.I.T., 2012b. Cold Nuclear Fusion, Create Space Publisher, USA, July 2012, ISBN-10: 978-1- 4782-3426-5, pp: 80.

Petrescu, F.I.T., 2014. Nuclear fusion, Infinite Energy 20: 44-47.

Petrescu, F.I.T., A. Apicella, R.V. Petrescu, S. Kozaitis and R. Bucinell et al., 2016. Environmental protection through nuclear Energy. Am. J. Applied Sci., 13: 941-946.

DOI: 10.3844/ajassp.2016.941.946

Shultis, J.K. and R.E. Faw, 2002. Fundamentals of Nuclear Science and Engineering. CRC Press, New York, ISBN-10: 0824708342, pp: 520.

Tomonaga, S.I., 1997. The Story of Spin. University of Chicago Press. ISBN-10: 9780226807942

Wichmann, E.H., 1983. The Berkeley Physics Quantum Physics Course. 1st Edn., Didactic Pedagogical, Bucharest. 